\title{
PENGARUH SELF IMAGE CONGRUENCE TERHADAP KEPUTUSAN PEMBELIAN DIMEDIASI OLEH BRAND TRUST PADA MASKAPAI PENERBANGAN DI INDONESIA
}

\author{
Salsabila Nadhifah \\ Universitas Singaperbangsa Karawang \\ salsabila.nadhifah18181@student.unsika.ac.id \\ Reminta Lumban Batu \\ Universitas Singaperbangsa Karawang \\ reminta.lumban@fe.unsika.ac.id
}

\begin{abstract}
The Indonesian aviation industry, especially domestic airlines, is booming and overgrowing with the emergence of many airlines since Law No. 15 of 1992 was enacted. This study aimed to see the effect of self-image congruence on purchasing decisions mediated by a brand trust on AirAsia Airlines. This research was conducted using descriptive and verification methods. The sampling technique of this research is nonprobability sampling using the Hair formula. The types of data used in this study are primary and secondary data. The data were processed using path analysis. This study proves that self-image congruence has a positive and significant effect on purchasing decisions through brand trust in Air Asia Airlines. This research implies that self-image congruence can indirectly influence purchasing decisions through brand trusts, which is seen from the actual indicator of self-image or how consumers see their true selves. Brand character indicators can make the brand have an essential role in determining consumer decision making to trust a brand, and this is because consumers make judgments before buying it.
\end{abstract}

Keywords: brand trust; purchase decision; self image congruance.

\section{PENDAHULUAN}

Perkembangaan teknologi di era globalisasi terus berkembang dengan pesat, mengakibatkan perubahan perilaku konsumen dalam melakukan keputusan pembelian (Mamahit et al., 2015). Perkembangan teknologi membuat persaingan pasar semakin kompetitif. Hal ini memicu konsumen menentukan pilihan produk yang tidak hanya didasarkan pada kebutuhan saja, namun pada pertimbangan-pertimbangan lainnya juga (Falsafani, 2020; Ratnawati \& Lestari, 2018).

Industri penerbangan merupakan industri yang bergerak dalam bidang transportasi udara yang dibutuhkan masyarakat. Dunia penerbangan pada era modern saat ini telah mencapai puncaknya sebagai transportasi masal andalan yang berbasis universal. PT AirAsia Indonesia Tbk merupakan salah satu perusahaan yang bergerak pada bidang usaha komersial berjadwal, yang diresmikan menjadi induk dari PT Indonesia AirAsia pada 29 Desember 2017. PT AirAsia Indonesia Tbk memiliki model usaha yang didasarkan pada filosofi biaya rendah yang menekankan kesederhanaan dan operasi yang efisien. PT AirAsia Indonesia berkomitmen penuh untuk memenuhi harapan para penumpangnya dengan terus mengurangi biaya, memberikan pelayanan terbaik, dan mencapai tingkat efisiensi tertinggi. Namun, pada Minggu 28 Desember 2014 pesawat yang dioperasikan Indonesia AirAsia yaitu pesawat A320 dengan nomor penerbangan QZ8501 untuk rute Surabaya-Singapura hilang kontak setelah 50 menit lepas landas dari Bandar udara Juanda, Surabaya. Peristiwa jatuhnya pesawat Airbus A320 yang dioperasikan Indonesia AirAsia di Selat Karimata ini mengakibatkan perusahaan cenderung mengalami penurunan (geraijasa.com, 2019).

Konsumen mempunyai peran penting bagi keberlangsungan suatu perusahaan. Proses pengambilan keputusan konsumen merupakan tahapan-tahapan yang dilakukan konsumen pada saat membeli suatu barang atau jasa. Jadi, keputusan pembelian adalah keputusan yang dibuat oleh konsumen karena ketertarikannya terhadap suatu produk atau jasa, dan ingin membeli, mencoba, menggunakan, atau 
Salsabila Nadhifah \& Reminta Lumban Batu. Pengaruh Self Image Congruence terhadap Keputusan Pembelian Dimediasi oleh Brand Trust pada Maskapai Penerbangan di Indonesia

memiliki produk tersebut (Marlius, 2017). Sebelum memutuskan untuk mengkonsumsi sebuah merek, konsumen akan melakukan pertimbangan secara rasional dan tidak rasional (Falsafani, 2020).

Salah satu variabel yang menyebabkan konsumen memutuskan pembelian secara tidak rasional adalah self image congruence (Falsafani, 2020). Menurut Sirgy (1986), self image congruence atau kesesuaian citra diri merupakan kesesuaian kerja pikiran dan konsep diri konsumen dengan sebuah citra yang dibangun oleh suatu produk atau jasa. Selain itu, konsumen akan membeli produk dan merek yang mereka yakini memiliki citra yang serupa dan/atau saling melengkapi dengan citra diri mereka, yaitu untuk mencapai kesesuaian citra. Citra merek yang baik akan berdampak baik juga pada perusahaan, sedangkan citra yang kurang baik dapat diartikan masyarakat mempunyai kesan yang negatif terhadap merek tersebut (Goh et al., 2016).

Brand trust merupakan kesediaan konsumen mengandalkan kemampuan merek untuk melakukan fungsinya (Chaudhuri \& Holbrook, 2001). Komponen kepercayaan dikatakan sebagai salah satu hal penting dalam perilaku pembelian. Ketika konsumen memiliki trust terhadap suatu merek maka konsumen yakin dengan kinerja merek tersebut sehingga memutuskan untuk membeli merek tersebut (Goh et al., 2016). Menurut Coulter \& Coulter (2002), variabel self image congruence berdampak pada pembangunan trust pada sebuah merek. Hal tersebut sejalan dengan penelitian Liu-Thompkins \& Tam (2013) pada restauran mewah yang menunjukkan bahwa self image congruence memiliki efek positif pada kepercayaan pelanggan. Berdasarkan uraian permasalahan tersebut, penelitian ini bertujuan untuk mengetahui seberapa besar pengaruh self image congruence terhadap keputusan pembelian dimediasi oleh brand trust pada maskapai penerbangan AirAsia.

\section{KAJIAN PUSTAKA DAN PENGEMBANGAN HIPOTESIS}

\section{Self Image Congruence}

Menurut Sirgy (1986), self image congruence adalah keselarasan dengan kerja pikiran antara konsep diri konsumen dengan sebuah citra yang dibangun oleh sebuah produk atau servis. Self image congruence menunjukkan tingkat di mana konsumen memandang diri mereka sebagai individu yang sesuai dengan tujuan produk tersebut diproduksi (Safitri \& Riptiono, 2020). Self image congruence adalah hubungan antara cara pandang individu memandang diri mereka sendiri dengan sebuah citra yang dibangun oleh suatu produk (Goh et al., 2016). Menurut teori self image congruence, konsumen akan memilih produk yang sesuai dengan citranya secara konsisten. Hal ini dimaksudkan untuk menunjukkan konsep diri mereka tentang bagaimana mereka ingin dilihat dalam lingkungan sosialnya secara konsisten dan juga dapat meningkatkan harga diri mereka ketika mereka muncul di tempattempat umum (Sirgy, 1986).

\section{Brand Trust}

Kepercayaan merek merupakan persepsi konsumen tentang keandalan berdasarkan pengalaman atau serangkaian transaksi atau interaksi yang ditandai dengan terpenuhinya harapan kinerja dan kepuasan terhadap suatu produk (Iman, 2017). Menurut Lau \& Lee (1999) kepercayaan pelanggan terhadap suatu merek (brand trust) didefinisikan sebagai keinginan pelanggan untuk mengandalkan suatu merek dengan risiko yang dihadapi dengan harapan merek tersebut akan menghasilkan hasil yang positif. Kepercayaan merek dapat memunculkan keyakinan seseorang tentang kinerja pada suatu merek (Goh et al., 2016). Liu et al. (2011) menyatakan bahwa kepercayaan merek merupakan faktor mediator penting pada perilaku pelanggan sebelum dan sesudah pembelian produk dan itu menyebabkan loyalitas jangka panjang dan memerkuat hubungan antara dua pihak.

\section{Keputusan Pembelian}

Menurut Kotler \& Keller (2016) keputusan pembelian adalah sejumlah langkah yang diambil oleh seorang konsumen sebelum mengambil keputusan untuk membeli suatu produk. Sedangkan menurut Marlius (2017), keputusan pembelian adalah keputusan yang dibuat oleh konsumen karena ketertarikannya terhadap suatu produk atau jasa, dan ingin membeli, mencoba, menggunakan, atau memiliki produk tersebut. Keputusan pembelian merupakan proses perilaku yang harus dilakukan untuk memecahkan suatu masalah yang diarahkan pada sasarannya, sehingga perusahaan dapat 
mencapai sasaran (Mamahit et al., 2015). Keputusan pembelian konsumen umumnya dipertimbangkan atas dasar proses yang terdiri dari tahap-tahap proses keputusan pembelian (Saidani \& Ramadhan, 2013).

\section{Hubungan antar Variabel}

Self image congruence atau kesesuaian citra diri di mana konsumen cenderung membeli barang dan jasa yang mempunyai citra atau kepribadian yang sesuai dengan citra diri mereka (Nofianti, 2014). Self image congruence merupakan faktor internal dari individu yang berhubungan dengan perilaku konsumsi seseorang (Fatimah et al., 2013). Perilaku konsumen merupakan suatu proses atau tindakan yang dilakukan oleh seseorang untuk menggunakan suatu produk berdasarkan pengalamannya atau pengalaman orang lain terhadap produk tersebut (Pratiwi et al., 2013). Menurut Mamahit et al. (2015), brand trust adalah suatu perasaan aman yang dimiliki konsumen akibat dari interaksinya dengan sebuah merek, yang berdasarkan persepsi bahwa merek tersebut dapat diandalkan dan bertanggung jawab atas kepentingan dan keselamatan dari konsumen. Kepercayaan merek dipengaruhi oleh konsep diri (self image congruence). Berdasarkan hasil penelitian Goh et al. (2016), konsep diri memiliki kesesuaian terhadap kepercayaan merek. Penelitian ini juga didukung oleh Falsafani (2020) bahwa terdapat pengaruh yang signifikan dari variabel self image congruence terhadap brand trust. Hal tersebut juga selaras dengan Chen-Yu et al. (2016) di mana konsumen merasa tertarik terlebih dahulu dan berharap produk tersebut dapat mengekspresikan kebutuhannya guna mencitrakan diri mereka sehingga menciptakan kepercayaan pada sebuah brand.

\section{H1: Terdapat pengaruh positif dari self image congruence terhadap brand trust.}

Keputusan Pembelian merupakan sebuah proses yang dilakukan oleh konsumen dalam melakukan pembelian produk barang ataupun jasa (Ramadhani \& Prabawani, 2019). Menurut Kotler \& Keller (2016), proses keputusan pembelian melalui model lima tahap yaitu: pengenalan masalah, pencarian informasi, evaluasi alternatif, keputusan pembelian, dan perilaku pasca pembelian. Dalam melakukan keputusan pembelian ketika konsumen memiliki keyakinan dan sikap setelah mendapatkan informasi dan pengalaman maka konsumen akan memutuskan pembelian (Devindiani \& Wibowo, 2016). Kepercayaan merek berpengaruh terhadap keputusan pembelian (Ramadhani \& Prabawani, 2019). Hasil ini sejalan dengan penelitian Mamahit et al. (2015) dan Nofianti (2014) bahwa ketika konsumen memiliki trust terhadap suatu merek maka konsumen yakin dengan kinerja merek tersebut sehingga memutuskan untuk membeli merek tersebut.

H2: Terdapat pengaruh positif dari brand trust terhadap keputusan pembelian.

Self image congruence adalah bagian penting dalam setiap diskusi mengenai kepribadian manusia. Self image ini sendiri merupakan sifat manusia yang unik, sehingga dapat digunakan untuk membedakan manusia dengan makhluk hidup lainnya (Wuryanti \& Zahara, 2019). Perilaku konsumen ini erat kaitannya dengan proses pengambilan keputusan seorang konsumen untuk menggunakan atau membeli barang dan jasa guna memenuhi kebutuhannya (Wuryanti \& Zahara, 2019). Menurut Wuryanti \& Zahara (2019), self image congruence tidak berpengaruh terhadap keputusan pembelian konsumen. Hal tersebut sejalan dengan penelitian Ramadhani \& Prabawani (2019) bahwa brand trust berpengaruh terhadap keputusan pembelian yang artinya bahwa self image congruence tidak berpengaruh langsung terhadap keputusan pembelian melainkan ada variabel lain yang memengaruhi keputusan pembelian. Mahuda (2017) juga menunjukkan bahwa terdapat hubungan yang signifikan antara brand trust dan keputusan pembelian pelanggan Butik Meccanism, di mana kepercayaan pada sebuah merek merupakan hal yang dapat memengaruhi perilaku konsumen. Kepercayaan merek yang baik dan kuat dari konsumen tersebut akan menciptakan keputusan pembelian.

H3: Terdapat pengaruh positif dari self image congruence terhadap keputusan pembelian yang dimediasi oleh brand trust. 
Salsabila Nadhifah \& Reminta Lumban Batu. Pengaruh Self Image Congruence terhadap Keputusan Pembelian Dimediasi oleh Brand Trust pada Maskapai Penerbangan di Indonesia

\section{METODE PENELITIAN}

Jenis penelitian ini merupakan penelitian deskriptif verifikatif dengan explanatory survey method. Jenis data yang digunakan dalam penelitian ini adalah data primer dan data sekunder. Populasi dalam penelitian ini adalah pengikut akun social media maskapai penerbangan AirAsia yang jumlah pastinya terus berubah. Metode yang digunakan dalam pengambilan sampel adalah nonprobability sampling, yaitu menggunakan teknik pengambilan sampel convenience sampling. Penentuan jumlah sampel minimal pada penelitian ini mengacu pada pernyataan Hair et al., (2010) bahwa banyaknya sampel sebagai responden harus disesuaikan dengan banyaknya indikator pertanyaan yang digunakan pada kuesioner, dengan asumsi $\mathrm{n}$ x 5 observed variabel (indikator) sampai dengan $\mathrm{n} \times 10$ observed variable (indikator). Penelitian menggunakan 10 indikator dikali 10 sama dengan 100 responden. Pengumpulan data primer dilakukan dengan menyebarkan kuisioner menggunakan google form, yang dilakukan secara online melalui direct message social media dengan menyediakan alternatif jawaban kepada para responden yang berkaitan dengan variabel terkait. Teknik analisis data untuk menguji hipotesis menggunakan uji statistik di antaranya uji normalitas, uji Goodness of Fit (GOF), dan uji hipotesis dengan persamaan analisis jalur (path analysis). Penelitian ini menggunakan program software Lisrel 8.80 student untuk menunjukkan hubungan antara variabel terikat dengan variabel bebas yang dimediasi oleh variabel moderating melalui analisis regresi jalur.

\section{HASIL DAN PEMBAHASAN}

\section{Analisis Jalur (Path Analysis)}

Path analysis atau analisis jalur menunjukkan seberapa kuat efek atau pengaruh self image congruence, terhadap keputusan pembelian yang dimediasi oleh brand trust pada pengguna maskapai penerbangan Air Asia. Hasil pengolahan data untuk analisis terlihat pada Gambar 1.

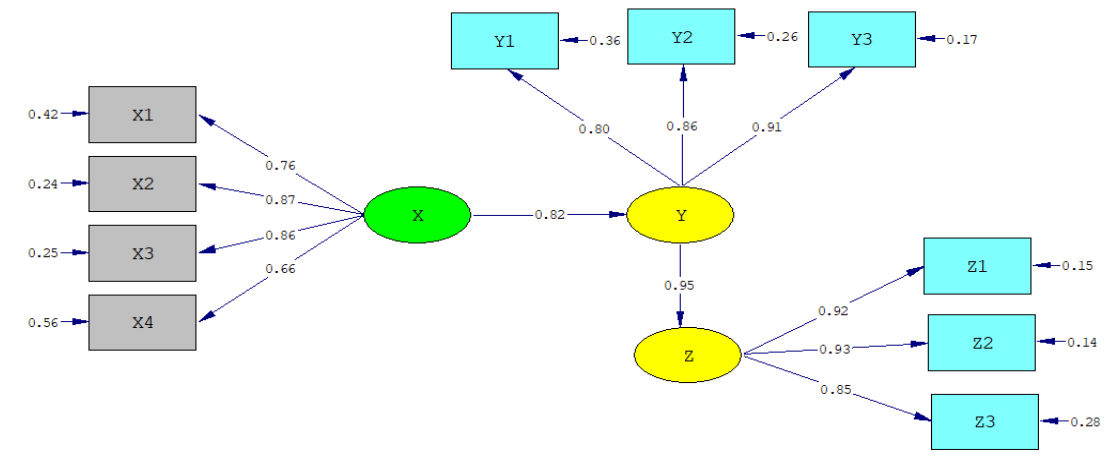

Sumber: Data diolah (2021)

\section{Gambar 1. PATH DIAGRAM}

\section{Uji Normalitas Data}

Hasil uji normalitas disajikan pada Lampiran 1. Setelah dilakukan transformasi data menggunakan normal score dapat diketahui bahwa setiap indikator berdistribusi normal karena $\mathrm{Z}$ score Skewness dan kurtosis berada di antara -1,96 hingga 1,96 dan P-Value $>0,05$.

Tabel 1.

MULTIVARIATE NORMALITY DENGAN NORMAL SCORE

\begin{tabular}{rrrrrrrr}
\hline Value & $\begin{array}{c}\text { Skewness } \\
\text { Z-Score }\end{array}$ & P-Value & Value & Z-Score & P-Value & \multicolumn{2}{c}{ Skewness and Kurtosis } \\
Chi-Square & P-Value \\
\hline 24,855 & 7,421 & 0,000 & 137,909 & 4,570 & 0,000 & 75,959 & 0,000 \\
\hline
\end{tabular}

Sumber: Data diolah (2021) 
Selanjutnya dilakukan uji multivariate normality. Hasil pada tabel 1 menunjukkan normalitas multivariate tetap tidak normal karena $\mathrm{Z}$ score tidak bernilai diantara $-1,96$ hingga 1,96 . Normalitas univariate telah menunjukkan bahwa sebagian besar data berdistribusi normal, maka dari itu analisis uji selanjutnya dapat dilakukan.

\section{Uji Kecocokan Model (Goodness of fit model)}

Tabel 2.

GOODNESS OF FIT MODEL

\begin{tabular}{ccc}
\hline Overall Model Fit Test Size & Benchmark Value for Model fit & Fit of Model to Data \\
\hline Probability from $X$ count - & $\geq 0,05$ & False \\
RMSEA $-0,045$ & $\leq 0,08$ & Yes \\
NFI $-0,98$ & $\geq 0,9$ & Yes \\
NNFI $-0,99$ & $\geq 0,9$ & Yes \\
CFI $-1,00$ & $\geq 0,90$ & Yes \\
IFI $-1,00$ & $\geq 0,9$ & Yes \\
RFI $-0,97$ & $\geq 0,9$ & Yes \\
RMR $-0,29$ & $\leq 0.05$ & False \\
SRMR $-0,043$ & $\leq 0,05$ & Yes \\
GFI $-0,93$ & $\geq 0,9$ & Yes \\
AGFI $-0,88$ & $0,8 \leq$ AGFI $\leq 0,9$ & Yes (Marginal Fit) \\
\hline
\end{tabular}

Sumber: Data diolah (2021)

Berdasarkan Tabel 2, diperoleh bahwa 2 ukuran dari 11 ukuran GOF kurang baik dan 9 ukuran dari 11 ukuran menunjukkan kecocokan yang baik, sehingga model struktural yang diusulkan memiliki kesesuaian yang baik dengan sampel penelitian. Hal ini berarti bahwa model penelitian yang dihasilkan adalah valid, data empiris yang diperoleh identik dengan teori yang telah dibangun berdasarkan model analisis jalur (path analysis), dan model fit yang dapat diartikan sebagai gambaran hubungan yang cocok atau selaras diantara variabel-variabel yang diteliti.

\section{Analisis Structural Equation Modeling (SEM)}

Hasil structural equation dapat dilihat di persamaan (1) dan (2). Berdasarkan hasil pengolahan data tersebut dapat diketahui bahwa variabel self image congruence berpengaruh terhadap variabel brand trust dengan pengaruh sebesar 0,81 dan standar error sebesar 0,11 dan variabel ini berpengaruh secara signifikan karena memiliki nilai $t_{\text {hitung }}$ sebesar 7,57 > nilai $t_{\text {tabel }}$ yaitu sebesar 1,96 untuk $\alpha=0,05$ dan $\mathrm{df}=\mathrm{n}-2(100-2)$. Variabel brand trust berpengaruh terhadap variabel keputusan pembelian (Z) sebesar 0,96 dan standar error sebesar sebesar 0,095 dan variabel ini berpengaruh secara signifikan karena memiliki nilai $t_{\text {hitung }}$ sebesar $10,10>$ nilai $t_{\text {tabel }}$ yaitu sebesar 1,96. Kemudian diperoleh juga persamaan variabel brand trust yang dapat dilihat nilai $R^{2}$ sebesar 0,66 atau $66 \%$, yang artinya variabel self image congruence memengaruhi variabel brand trust sebesar $66 \%$, sedangkan sisanya dipengaruhi oleh variabel lain. Diperoleh juga persamaan variabel keputusan pembelian yang dapat dilihat nilai $R^{2}$ sebesar 0,91 atau $91 \%$, yang artinya variabel brand trust memengaruhi variabel keputusan pembelian sebesar $91 \%$, sedangkan sisanya dipengaruhi oleh variabel lain.

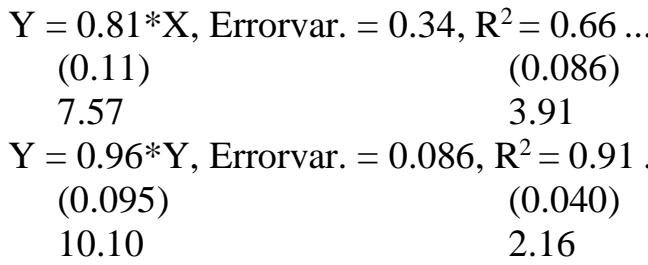


Salsabila Nadhifah \& Reminta Lumban Batu. Pengaruh Self Image Congruence terhadap Keputusan Pembelian Dimediasi oleh Brand Trust pada Maskapai Penerbangan di Indonesia

\section{Pengujian Hipotesis}

Pengujian hipotesis didasarkan pada nilai yang terdapat pada analisis structural model, tingkat signifikansi path coefficient didapat dari nilai-t. Batas nilai atau threshold pengujian hipotesis yaitu nilai-t muatan faktornya (factor loadings) lebih besar dari nilai kritis $(\geq 1.96)$. Path diagram dari tvalue dapat dilihat di Gambar 2.

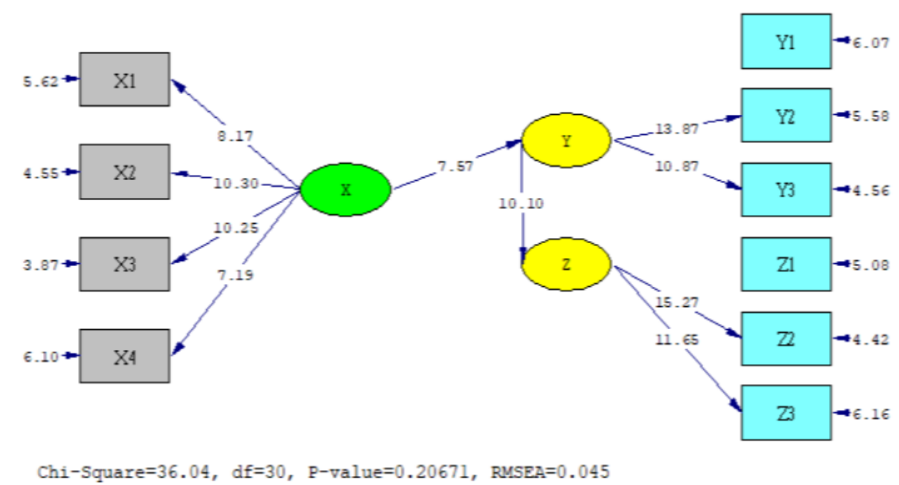

Sumber: Data diolah (2021)

Gambar 2. PATH DIAGRAM T-VALUE

Hasil pengujian hipotesis dari hasil estimasi model struktural disajikan pada Tabel 3. Berdasarkan Tabel 3, hasil path diagram $t$-value diperoleh nilai-t $=7,57>1,96$. Dengan demikian, hipotesis H1, yang menyatakan self image congruence memiliki efek positif yang signifikan terhadap brand trust dapat diterima. Hasil path diagram $t$-value diperoleh nilai-t $=10,10>1,96$. Dengan demikian, hipotesis $\mathrm{H} 2$, yang menyatakan brand trust memiliki efek positif yang signifikan terhadap keputusan pembelian dapat diterima. Terdapat pengaruh positif dari self image congruence terhadap keputusan pembelian yang dimediasi oleh brand trust dengan taraf nyata $(\alpha)$ sebesar $5 \%=0,05$ dan hasil estimasi model struktural diperoleh pengaruh tidak langsung di mana $(0,81 \times 0,96)=0,778$. Dengan demikian, hipotesis $\mathrm{H} 3$, yang menyatakan self image congruence memiliki efek positif yang signifikan terhadap keputusan pembelian yang dimediasi oleh brand trust dapat diterima.

Tabel 3.

HASIL SIGNIFIKASI VARIABEL

\begin{tabular}{|c|c|c|c|c|}
\hline \multicolumn{2}{|r|}{ Hipotesis } & \multicolumn{2}{|c|}{ Hasil Uji Statistik } & \multirow{2}{*}{$\frac{\text { Keterangan }}{\text { Signifikan }}$} \\
\hline H1 & $\begin{array}{c}\text { Self Image Congruence } \rightarrow \\
\text { Brand Trust }\end{array}$ & Nilai-t 7,57 & $\begin{array}{l}\text { Standardized Path } \\
\text { Coefficience } 0.81\end{array}$ & \\
\hline $\mathrm{H} 2$ & $\begin{array}{c}\text { Brand Trust } \rightarrow \text { Keputusan } \\
\text { Pembelian }\end{array}$ & Nilai-t 10,10 & $\begin{array}{l}\text { Standardized Path } \\
\text { Coefficience } 0.96\end{array}$ & Signifikan \\
\hline $\mathrm{H} 3$ & $\begin{array}{c}\text { Self Image Congruence } \rightarrow \text { Brand } \\
\text { Trust } \rightarrow \text { Keputusan Pembelian }\end{array}$ & $\begin{array}{l}\text { Indirect effect } 0,778 \\
\quad(0,81 \times 0,96)\end{array}$ & Total Effect 0,778 & Signifikan \\
\hline
\end{tabular}

Sumber: Data diolah (2021)

\section{Pengaruh Self Image Congruence terhadap Brand Trust}

Hasil penelitian menunjukkan bahwasannya self image congruence memiliki pengaruh signifikan terhadap brand trust pada pengguna maskapai penerbangan AirAsia. Hal tersebut dikarenakan self image congruence atau kesesuaian citra diri ketika konsumen membeli barang atau jasa yang mempunyai citra atau kepribadian yang sesuai dengan diri mereka. Ketika konsumen memutuskan untuk membeli suatu barang atau jasa yang sesuai dengan citra dirinya maka bisa menumbuhkan kepercayaan konsumen tersebut terhadap sebuah merek. Penelitian ini juga didukung dan sejalan dengan penelitian sebelumnya yang dilakukan oleh (Falsafani, 2020) yang menyatakan bahwa terdapat pengaruh yang signifikan dari varabel self image congruence terhadap brand trust. Terdapat kesesuaian antara citra dari konsumen dengan citra produk, sehingga saat melakukan keputusan 
pembelian, pembeli akan mempercayai produk tersebut. Berdasarkan hasil kuisioner, perusahaan dapat memerhatikan variabel self image congruence dan brand trust khususnya di bagian actual self image dan brand character sebagai bahan evaluasi. Perusahaan dapat meningkatkan self image congruence konsumen dengan meningkatkan kualitas-kualitas produk atau jasa yang ditawarkan. Ketika konsumen merasa sudah sesuai dan merasa tertarik karena merasa produk tersebut dapat mewakili kebutuhan citra diri mereka, sehingga dari sanalah kepercayaan pada sebuah brand lahir. Hal serupa juga sejalan dengan Goh et al. (2016) bahwa self image congruence berpengaruh terhadap brand trust.

\section{Pengaruh Brand Trust terhadap Keputusan Pembelian}

Berdasarkan hasil penelitian, terdapat pengaruh signifikan brand trust terhadap keputusan pembelian pada pengguna maskapai penerbangan AirAsia. Hasil penelitian ini banyak didukung oleh penelitian sebelumnya. Mamahit et al. (2015) menyatakan bahwa brand trust secara parsial berpengaruh signifikan terhadap keputusan pembelian Toyota All New Yaris di PT. Hasjrat Abadi Manado. Ramadhani \& Prabawani (2019) menyatakan bahwa brand trust mempunyai pengaruh positif yang signifikan terhadap keputusan pembelian konsumen Tropicana Slim Di Kota Semarang. Kuatnya Tropicana slim di mata responden salah satunya dipengaruhi oleh persepsi responden atas brand trust, dapat diketahui persepsi brand trust yang tinggi lebih banyak dipengaruhi oleh tingkat reputasi produk tropicana slim di mata responden. Berdasarkan hasil kuisioner, diharapkan perusahaan senantiasa meningkatkan kualitas pelayanan yang berpengaruh terhadap brand trust, di mana konsumen tertarik untuk menetapkan keputusan pembelian pada maskapai penerbangan AirAsia yang sekaligus dapat meningkatkan penjualan tiket.

Hasil penelitian ini juga sejalan dengan logika dan teori di mana ketika konsumen melakukan keputusan pembelian ketika konsumen memiliki keyakinan dan sikap setelah mendapatkan informasi dan pengalaman terhadap brand tersebut maka dalam diri konsumen akan tumbuh trust atau kepercayaan terhadap brand tersebut sehingga memutuskan untuk melakukan pembelian (Goh et al., 2016).

\section{Pengaruh Self Image Congruence terhadap Brand Trust serta Dampaknya terhadap Keputusan Pembelian}

Menurut MacKinnon et al. (2002) untuk membuktikan suatu variabel sebagai intervening, apabila Variabel $\mathrm{X}$ terhadap $\mathrm{Y}$ signifikan, sudah cukup membuktikan adanya mediasi, hal itu semakin diperkuat dengan hasi perhitungan di mana terdapat pengaruh signifikan antara variabel $\mathrm{Y}$ terhadap $\mathrm{Z}$ yang artinya variabel independen memengaruhi mediator dan mediator memengaruhi dependen. Berdasarkan hasil kuisioner self image congruence secara tidak langsung dapat memengaruhi keputusan pembelian melalui brand trust, peryataan tersebut dilihat dari indikator actual self image atau bagaimana konsumen melihat diri mereka yang sesungguhnya. Indikator brand character dapat membuat brand memiliki peran yang penting dalam menentukan pengambilan keputusan konsumen untuk mempercayai suatu merek, hal ini disebabkan konsumen melakukan penilaian sebelum membelinya. Hasil penelitian sejalan dengan penelitian yang dilakukan oleh Falsafani (2020) bahwa self-image congruence berpengaruh signifikan terhadap brand trust pada pengguna iPhone milenial di Indonesia. Keputusan pembelian merupakan sebuah proses yang dilakukan oleh konsumen dalam melakukan pembelian produk barang ataupun jasa. Dalam melakukan keputusan pembelian ketika konsumen memiliki keyakinan dan sikap setelah mendapatkan informasi dan pengalaman terhadap brand tersebut maka dalam diri konsumen akan tumbuh trust atau kepercayaan terhadap brand tersebut sehingga memutuskan untuk melakukan pembelian.

Brand trust atau kepercayaan merek berpengaruh terhadap keputusan pembelian. Hal tersebut sejalan dengan penelitian Goh et al. (2016), ketika konsumen memiliki trust terhadap suatu brand maka konsumen yakin dengan kinerja merek tersebut sehingga memutuskan untuk membeli brand tersebut. Berdasarkan penelitian yang dilakukan pada maskapai penerbangan AirAsia, terdapat pengaruh signifikan pada variabel self image congruence terhadap brand trust yang berdampak pada keputusan konsumen untuk membeli tiket atau menggunakan jasa maskapai penerbangan Air Asia yang di mana 
Salsabila Nadhifah \& Reminta Lumban Batu. Pengaruh Self Image Congruence terhadap Keputusan Pembelian Dimediasi oleh Brand Trust pada Maskapai Penerbangan di Indonesia

brand trust menjadi variabel interveningnya dan yang menjadi novelty dalam penelitian ini yaitu adanya penggabungan penelitian self image congruence yang berpengaruh terhadap keputusan pembelian dengan dimediasi oleh brand trust.

Secara keseluruhan hasil penelitian ini menjawab semua hipotesis yang diajukan, self image congruence terhadap brand trust dan keputusan pembelian. Brand trust juga mampu memediasi pengaruh self image congruence terhadap keputusan pembelian. Atas dasar hal tersebut, implikasi manajerial dari penelitian ini adalah perusahaan penerbangan harus memerhatikan faktor kualitas layanan yang diberikan agar terbangun image dan citra positif di mata konsumen maupun calon konsumen. Hal ini penting mengingat self image congruence merupakan kerja pikiran antara konsep diri konsumen dengan sebuah citra yang dibangun oleh sebuah produk atau servis. Selain itu perusahaan penerbangan juga harus memerhatikan brand trust karena dipercaya berpengaruh terhadp keputusan pembelian tiket pesawat.

\section{KESIMPULAN}

Berdasarkan hasil penelitian yang telah dilakukan, maka dapat diambil kesimpulan bahwa terdapat pengaruh positif dan signifikan antara self image congruence terhadap brand trust pada pengguna maskapai penerbangan AirAsia. Hasil analisis jalur (path analysis) menggunakan nilai estimates menunjukkan yang memengaruhi brand trust secara signifikan pada maskapai penerbangan air asia adalah self image congruence, sama halnya dengan brand trust yang memiliki pengaruh positif dan signifikan terhadap keputusan pembelian pada maskapai penerbangan AirAsia. Hasil analisis jalur (Path Analysis) menggunakan nilai estimates menunjukkan yang memengaruhi keputusan pembelian secara signifikan atau nyata pada maskapai penerbangan AirAsia adalah brand trust. Selain itu juga terdapat pengaruh positif dan signifikan antara self image congruence terhadap brand trust yang berdampak pada keputusan pembelian pada maskapai penerbangan AirAsia. Hasil analisis jalur (Path Analysis) menunjukkan self image congruence dimediasi oleh brand trust secara tidak langsung memengaruhi keputusan pembelian. Kerangka konseptual yang digunakan dalam penelitian ini hanya menghubungkan variabel-variabel yang diperkirakan memiliki hubungan dengan variabel terikat, sehingga masih ada kemungkinan variabel lain yang tidak termasuk dalam kerangka konseptual. Penelitian selanjutnya diharapkan dapat melakukan penelitian lanjutan untuk mencari tahu variabel yang memengaruhi keputusan pembelian dengan menggunakan variabel independen dan variabel mediasi lainnya, misalnya green advertising dan service quality.

\section{DAFTAR PUSTAKA}

Chaudhuri, A., \& Holbrook, M. B. (2001). The Chain of Effects from Brand Trust and Brand Affect to Brand Performance: The Role of Brand Loyalty. Journal of Marketing, 65(2), 81-93.

Coulter, K. S., \& Coulter, R. A. (2002). Determinants of trust in a service provider: the moderating role of length of relationship. Journal of Services Marketing, 16(1), 35-50. https://doi.org/10.1108/08876040210419406

Devindiani, E., \& Wibowo, L. A. (2016). Pengaruh Experiential Marketing Terhadap Customer Satisfaction Serta Dampaknya Pada Customer Loyalty (Survei pada Pengguna Smartphone di Komunitas Online Apple dan Samsung Regional Bandung). Journal of Business Management Education (JBME), 1(1), 149-159. https://doi.org/10.17509/jbme.v1i1.2284

Falsafani, M. (2020). Pengaruh Self-Image Congruence Terhadap Brand Association, Perceived Quality , Brand Trust, Dan Brand Loyalty Pada Milenial Di Indonesia. Jurnal Manajemen Dan Bisnis Indonesia, 6(1), 1-11.

Fatimah, S., Rosliana, L., \& Sulistiani, N. W. (2013). Pengaruh Gaya Hidup Dan Konsep Diri Terhadap Pengambilan Keputusan Konsumen Dalam Memilih Coffeeshop Di Samarinda. Ejurnal.Untag-Smd.Ac.Id, 1(1), 1-8. 
Geraijasa.com. (2019). Analisa ancaman dan peluang Air Asia. 2019. https://geraijasa.com/2019/04/26/indonesia-airasia-analisa-peluang-ancaman-sebagaipemimpin-maskapai-penerbangan-rute-internasional-berbasis-tarif-rendah-di-indonesia/. Diakses 4 November 2020.

Goh, S. K., Jiang, N., \& Tee, P. L. (2016). The impact of brand trust, self-image congruence and usage satisfaction toward smartphone repurchase intention. International Review of Management and Marketing, 6(3), 436-441.

Iman, T. (2017). Pengaruh Brand Equity dan Brand Trust terhadap Loyalitas Pelanggan Teh Botol Sosro di Kota Bandung. Jurnal STEI Ekonomi, 26(2), 253-265. https://doi.org/10.36406/jemi.v26i2.227

Kotler, P., Keller, K. L., Manceau, D., \& Dubois, B. (2016). Marketing Management, 15e édition. New Jersy: Pearson Education.

Limakrisma, N., \& Purba, T. P. (2017). Manajemen Pemasaran. Jakarta: Mitra Wacana Media.

Liu-Thompkins, Y., \& Tam, L. (2013). Not all repeat customers are the same: Designing effective cross-selling promotion on the basis of attitudinal loyalty and habit. Journal of Marketing, 77(5), 21-36. https://doi.org/10.1509/jm.11.0508

Liu, C. T., Guo, Y. M., \& Lee, C. H. (2011). The effects of relationship quality and switching barriers on customer loyalty. International Journal of Information Management, 31(1), 71-79. https://doi.org/10.1016/j.ijinfomgt.2010.05.008

MacKinnon, D. P., Lockwood, C. M., Hoffman, J. M., West, S. G., \& Sheets, V. (2002). A comparison of methods to test mediation and other intervening variable effects. Psychological Methods, 7(1), 83-104. https://doi.org/10.1037/1082-989x.7.1.83

Mahuda, F. D. (2017). Pengaruh Brand Personality Dan Brand Trust Terhadap Keputusan Pembelian (Studi Kasus Butik Meccanism). Al-Infaq: Jurnal Ekonomi Islam, 8(2), 151-167. https://doi.org/10.32507/ajei.v8i2.17

Mamahit, P., Soegoto, A. S., \& Tumbuan, W. A. (2015). Pengaruh Brand Image, Brand Trust, Dan Kualitas Produk Terhadap Keputusan Pembelian Mobil Toyota All New Yaris Pada Pt. Hasjrat Abadi Manado. Jurnal Berkala Ilmiah Efisiensi, 15(05), 777-787.

Marlius, D. (2017). Keputusan Pembelian Berdasarkan Faktor Psikologis Dan Bauran Pemasaran PT. Intercom Mobilindo Padang. Jurnal Pundi, 01(8.5.2017), 57-66.

Nofianti, R. (2014). Pengaruh Threat Emotion Konsumen Dan Brand Trust Terhadap Keputusan Pembelian Produk Gadget. Jurnal Economia, 10(2), 194-200. https://doi.org/10.21831/economia.v10i2.7545

Pratiwi, M. S., Suwendra, I. W., \& Yulianthini, N. N. (2013). Pengaruh Citra Perusahaan, Citra Produk dan Citra Pemakai Terhadap Keputusan Pembelian Produk Foremost pada Distro Ruby Soho di Singaraja. Jurnal Jurusan Manajemen, 2(1), 1-12.

Ramadhani, F., \& Prabawani, B. (2019). Pengaruh Threat Emotion Dan Brand Trust Terhadap Keputusan Pembelian Tropicana Slim Di Kota Semarang. Jurnal Ilmu Administrasi Bisnis, 8(4), 13-21.

Ratnawati, A., \& Lestari, A. A. (2018). Peran Brand Trust Dalam Memediasi Brand Experience, Brand Personality Dan Brand Community Terhadap Brand Loyalty. Jurnal Ekonomi Dan 
Salsabila Nadhifah \& Reminta Lumban Batu. Pengaruh Self Image Congruence terhadap Keputusan Pembelian Dimediasi oleh Brand Trust pada Maskapai Penerbangan di Indonesia

Bisnis, 19(2), 185-202. https://doi.org/10.30659/ekobis.19.2.185-202

Safitri, L., \& Riptiono, S. (2020). Pengaruh Self Image Congruence, Luxury Value Dan Product Attribute Terhadap Repurchase Intention Melalui Satisfaction Sebagai Variabel Intervening. Jurnal Ilmiah Mahasiswa Manajemen, Bisnis Dan Akuntansi (JIMMBA), 2(4), 681-688. https://doi.org/10.32639/jimmba.v2i4.591

Saidani, B., \& Ramadhan, D. R. (2013). Pengaruh Iklan Dan Atribut Produk Terhadap Keputusan Pembelian Smartphone Samsung Seri Galaxy (Survei Pada Pelanggan ITC Roxy Mas). JRMSI Jurnal Riset Manajemen Sains Indonesia, 4(1), 53-73. http://journal.unj.ac.id/unj/index.php/jrmsi/article/view/778

Sirgy, M. J. (1986). Self-Congruity: Toward a Theory of Personality and Cybernetics. New York: Praeger.

Wuryanti, L., \& Zahara, Y. (2019). Pengaruh Gaya Hidup, Konsep Diri, Harga Dan Kelas Sosial Terhadap Pengambilan Keputusan Pembelian Konsumen Di Coffeshop Kedai Kopi Pacar Hitam Lampung. Jurnal Riset Akuntansi Dan Manajemen, 8(1), 1-9. https://core.ac.uk/download/pdf/353678276.pdf

\section{Lampiran 1. UNIVARIATE NORMALITY DENGAN NORMAL SCORE}

\begin{tabular}{crrrrrr}
\hline & \multicolumn{2}{c}{ Skewness } & \multicolumn{2}{c}{ Kurtosis } & \multicolumn{2}{c}{ Skewness and Kurtosis } \\
Variable & Z-Score & P-Value & Z-Score & P-Value & Chi-Square & P-Value \\
\hline X1 & $-0,133$ & 0,894 & $-0,001$ & 0,999 & 0,018 & 0,991 \\
X2 & 0,018 & 0,985 & 0,085 & 0,932 & 0,008 & 0,996 \\
X3 & $-0,013$ & 0,990 & $-0,247$ & 0,805 & 0,061 & 0,970 \\
X4 & 0,369 & 0,712 & $-0,380$ & 0,704 & 0,280 & 0,869 \\
Y1 & $-0,164$ & 0,870 & $-0,445$ & 0,657 & 0,224 & 0,894 \\
Y2 & $-0,303$ & 0,762 & $-0,511$ & 0,609 & 0,353 & 0,838 \\
Y3 & $-0,146$ & 0,884 & $-0,342$ & 0,733 & 0,138 & 0,933 \\
Z1 & $-0,152$ & 0,879 & $-0,388$ & 0,698 & 0,173 & 0,917 \\
Z2 & $-0,306$ & 0,760 & $-0,751$ & 0,453 & 0,658 & 0,720 \\
Z3 & $-0,061$ & 0,951 & $-0,442$ & 0,658 & 0,200 & 0,905 \\
\hline
\end{tabular}

Sumber: Data diolah (2021) 